\title{
EFFECT OF DIFFERENT INDUCERS ON CONTROLLING DAMPING-OFF AND WILT DISEASES OF LUPINE
}

\author{
Marwa A.M. Atwa*, Sarhan E.A.D. and Zian A.H. \\ Legume and Forage Diseases Research Dept., Plant Pathology Research Institute, Agricultural \\ Research Centre, Giza, Egypt \\ *Corresponding author: marwashehatas@yahoo.com
}

Received 9 July, 2019

Accepted 4 August, 2019

\section{ABSTRACT}

The present investigation was carried out to study the effect of seed treatments of lupine plants (cv.Giza 2) with chemical inducers Bion ( $5 \mathrm{mM})$, salicylic acid $(5 \mathrm{mM})$ and saccharin $(3 \mathrm{mM})$ as well as Paenibacillus polymyxa and Trichoderma harzianum as biotic inducers on the infection with Rhizoctonia solani and Fusarium oxysporum f. sp. lupini under greenhouse and field conditions.

Under greenhouse condition (Agricultural Research Centre, Giza) all treatments significantly reduced the percentages of pre- and postemergence damping-off compared with the untreated control, the highest percentage of survived plants was achieved $92 \%$ by Bion and $T$. harzianum as well as fungicide Rizolex-T followed by salicylic acid and $P$. polymyxa as $88 \%$. On the other hand, all treatments decrease significantly the incidence and severity of wilt, also increased the percentage of survived plants compared with untreated control.

Under field conditions at Giza and Ismailia Agricultural Research Stations (Giza and Ismailia governorates) during winter season 2016-2017, all the treatments decreased the percentage of preand post-emergence damping-off as well as the percentage of wilted plants and increased the percentage of survived plants compared with untreated control in two locations. At Giza research station, the highest percentages of survived plants were recorded with Rizolex-T followed by Bion, $P$. polymyxa, and salicylic acid. While at Ismailia, the highest percentage of survived plants were recorded with Rizolex-T followed by Bion, P. polymyxa, T. harzianum, and salicylic acid. Meantime, these treatments improved growth parameters i.e. plant height, number of pods/plant, the weight of
\end{abstract}

seeds /plant and the weight of one hundred seed. The higher increase in seed yield (ton /feddan) was obtained with Rizolex-T and Bion treatments followed by Salicylic acid, P. polymyxa, and T. harzianum at two locations.

Activities of peroxidase (PO), polyphenol oxidase (PPO) enzymes and phenol content were determined. Bion treatment showed the highest increase in PO and PPO activity, and total phenols followed by salicylic acid and $P$. polymyxa treatments in the presence of $R$. solani or F. oxysporum. f. sp. lupini.

Keywords: Lupine, damping-off, wilt, induce resistance

\section{INTRODUCTION}

Lupine (Lupinus albus L.) is an economically valuable plant. Its seeds are utilized as a protein source for nutrition in various parts of the world; it has the highest protein percent of any grain legume (38-42\%), also for their adaptability to marginal soils and climates (Milford and Shield, 1996). In Egypt, in the last 10 years, the cultivated lupine area is decreased from 1574 ha producing 2885 tons during 2007 to 224 ha producing 420 tons during 2017 (FAOSTAT, 2019).

Soil-borne diseases caused heavy losses to lupine plants; they include damping-off, root rot and wilt diseases. They have common characteristics based on their close connection with the soil, which has a strong impact on their survival and capability to cause disease (Katan, 2017). In this respect, lupine plants are attacked by several pathogens which cause damping-off and wilt diseases leading to serious economic losses. Several soil-borne fungi were frequently reported as the 
causal organisms of such diseases namely; Fusarium oxysporum f.sp. lupini Snyder \& Hansen, Rhizoctonia solani Kühn, F. solani (Mat.) Sacc. and Macrophomina phaseolina (Tassi) Goid. (Zian, 2011; Abdel-Monaim et al 2016).

Chemical seed treatments still appear a major practice in agriculture and widely used to control fungal soil-borne diseases. However, fungicides have two major consequences, first: fungicide overuse threatens human health and causes ecological concerns; second: this practice leads to the emergence of fungicide-resistant microorganisms in the environment (Lamichhane et al 2017).

Induced resistance which utilizes natural defense of plants could be suggested as an alternative, non-classical and ecologically-friendly approach for plant protection (Edreva, 2004). There are two forms of systemic resistance, Systemic acquired resistance (SAR) and induced systemic resistance (ISR). Systemic acquired resistance (SAR) against pathogens can be induced by several synthetic chemical agents, such as salicylic acid, methyl salicylate, benzothiadiazole (Bion), $\beta$ aminobutyric acid, isonicotinic acid, benzoic acid, chitosan, saccharin and so forth which affect production of phenolic compounds and activation of various defense-related enzymes in plants (Thakur \& Sohal, 2013 and Walters et al 2013).

Induced systemic resistance (ISR) triggered by root-colonizing mutualistic microbes that are beneficial for plants, like rhizobacteria (PGPB or PGPR: Plant Growth Promoting Bacteria or Rhizobacteria) such as Pseudomonas fluorescens \& Paenibacillus polymyxa and fungi (PGPF: Plant Growth Promoting Fungi) such as Trichoderma spp. which can improve plant growth and benefit the adaptation of plants to adverse conditions (Pieterse et al 2014; Pii et al 2015). Most inducers reduce disease in the infected plants by $20 \%-85 \%$ (Walters et al 2013).

The objectives of the present study aimed to evaluate the efficacy of some chemical and biotic inducers for inducing resistance of lupine plants against damping-off and wilt diseases under greenhouse and field conditions. The reaction of host metabolic processes to induce an increase in phenolic compounds as a result of such treatments was studied.

\section{MATERIALS AND METHODS}

\section{Plant material}

Lupine seeds (Lupinus albus L.), cultivar Giza 2 were obtained from the Legume Res. Dept., Field Crops Res. Inst., ARC, Giza, Egypt.

\section{Pathogens}

The fungi $R$. solani Kühn and $F$. oxysporum f.sp. lupini Snyder \& Hansen were kindly provided by Legume and Forage Dis. Res. Dept., Plant Pathol. Res. Inst., Agric. Res. Centre, Giza, Egypt. The fungi were isolated from naturally infected lupine plants, showing damping-off and wilt symptoms. Their pathogenicity were updately confirmed and identified on the basis of cultural properties and microscopic morphological characters according to Sneh et al (1991) and Booth (1971).

\section{Preparation of pathogens inocula}

Inocula of $R$. solani and $F$. oxysporum f. sp. lupini were prepared by growing the fungi in glass bottles $500 \mathrm{cc}$ containing 100 gram sterilized sorghum grains medium. The bottles were inoculated with actively growing of equal five disks $(0.5 \mathrm{~cm})$ for each bottle of four days old $R$. solani or seven days old $F$. oxysporum f.sp. lupini cultures. The bottles were incubated at $25 \pm 1^{\circ} \mathrm{C}$ for 18 days; during this period the bottles were vigorously shaken daily for the first 4 days to encourage more rapid and uniform colonization of the sorghum grains then shaken every three days to ensure uniform distribution of the fungal growth. After the incubation period, the glass bottles were then evacuated and its content was air-dried at room temperature and crushed in a mill to pass through a 3-mm sieve. The dried crushed inocula stored in paper bags at $4 \pm 1^{\circ} \mathrm{C}$ until added to the soil within one week (Gaskill, 1968; Leslie \& Summerell, 2006).

\section{Chemical inducers}

Bion wettable granule (WG) $50 \%$, benzothiadiazole, (Syngenta Crop Protection, Inc); and salicylic acid (Sigma Aldrich, USA) and saccharin (MP Biomedicals, LLC) were used in this study. 


\section{Growing of biotic inducers}

A- Paenibacillus polymyxa: The culture of the bacteria $P$. polymyxa (isolate 9D14), previously isolated by Shehata et al (2006) and belongs to the collection of Plant Pathol. Dept., Fac. of Agric., Ain Shams Univ. was kindly provided. The culture of the bacteria was activated on fresh slants and after $24 \mathrm{hrs}$. was transferred to flasks with $50 \mathrm{ml}$ of nutrient yeast dextrose broth (NYDB) medium (per liter: nutrient broth $8 \mathrm{~g}$, yeast extract $5 \mathrm{~g}$ and dextrose $10 \mathrm{~g}$ ). The flasks were placed on a rotary shaker to grow at $120 \mathrm{rpm}$ for $66 \mathrm{hrs}$. at $24 \pm 1^{\circ} \mathrm{C}$.

B- Trichoderma harzianum: The fungus $T$. harzianum which isolated from the rhizosphere of faba bean by Elsaid et al (2005) and belongs to the collection of Plant Pathol. Dept., Fac. of Agric., Ain Shams Univ. was kindly provided. Its identification was previously confirmed on the basis of cultural properties and microscopic morphological characters according to Rifai (1969). The fungus was kept under a phosphate buffer $(\mathrm{pH} 6.5)$ at $4 \pm 0.5^{\circ} \mathrm{C}$ for longtime storage (Boeswinkel, 1976). Formulation of $T$. harzianum was prepared by growing the fungus in glass bottles $500 \mathrm{cc}$ containing $100 \mathrm{~g}$ sterilized sorghum grains medium (Rini \& Sulochana, 2007). The bottles were inoculated with actively growing $0.5 \mathrm{~cm}$ diameter mycelial disc of 7 days old $T$. harzianum culture. Five discs were used for inoculation for each bottle. The bottles were incubated at $27 \pm 1^{\circ} \mathrm{C}$ for 18 days and were vigorously shaken daily for the first 4 days to encourage more rapid and uniform colonization of the sorghum grains. At the end of the incubation period, the colonized sorghum grains by mycelium and conidia of $T$. harzianum were removed from the bottles and air dried in shade at room temperature, and was fine ground in a mill then sieved through 60 mesh $(0.25 \mathrm{~mm})$ sieve (Tewari \& Bhanu, 2004). The grinded sorghum grains were kept in a polythene bag and treated as formulated Trichoderma within one week.

\section{Seed and soil treatments}

Apparently, healthy uniformity seeds of lupine were surface disinfected by immersing in sodium hypochlorite (1\%) for $2 \mathrm{~min}$, and washed several times with sterilized water, then left to dry on screen cloth with paper towel underneath to absorb the excess water at room temperature for approximately two hours.
A) Chemical inducers treatments: The disinfected lupine seeds were soaked in aqueous solutions of the inducers (Bion, salicylic acid, and saccharin) for 6 hours on previous day of sowing at the rate of $5 \mathrm{mM}, 5 \mathrm{mM}$, and $3 \mathrm{mM}$ respectively, then the treated seeds were air-dried for $15 \mathrm{hrs}$. until sowing time.

B) The bacterial inducer treatment: After the growth of $P$. polymyxa, the liquid cultures media were then centrifuged undercooling $\left(4^{\circ} \mathrm{C}\right)$ at 7500 rpm for $10 \mathrm{~min}$. Then, the disinfected lupine seeds were soaked in the supernatant for 6 hours on the previous day of sowing. Cells of $P$. polymyxa in the precipitate were collected in a $20 \mathrm{~cm}$ Petri dish and the bacterial slurry was obtained by adding $1 \mathrm{ml}$ of $1 \%$ methylcellulose (Sigma-Aldrich, Milwaukee, WI, USA) in sterile distilled water to bacterial cells harvested from each Erlenmeyer flask. Healthy seeds of lupine that previously were soaked in the supernatant, were coated with the bacterial slurry, then spread on screen cloth with paper towel underneath to absorb the excess liquid, then the coated seeds were air-dried for $15 \mathrm{hrs}$. until sowing time. Enumeration of bacteria coated on seeds was performed by plate dilution method on the basis of colony-forming unit (CFU/seed) on nutrient yeast dextrose agar (NYDA) medium.

C) The T. harzianum treatment: Air-dried fine grinded sorghum grains which contained $3.7 \times 10^{9}$ (CFU) of $T$. harzianum (formulated Trichoderma) was used on previous day of sowing to coat the disinfected lupine seeds moistened with $1 \%$ methylcellulose in sterile distilled water as sticker, then the coated seeds were air-dried for $15 \mathrm{hrs}$. until sowing time.

D) Fungicide treatment: seed dressing was carried out to the disinfected lupine seeds by applying the Rizolex-T® 50\% WP (Tolclofos methyl + thiram), Sumitomo Chemical Company Ltd. at the recommended dose (3 $\mathrm{g} / \mathrm{kg}$ seeds) to the $1 \%$ methylcellulose (as sticker) moistened seeds in polyethylene bags and shaking well to ensure even distribution of the fungicide. The treatment was done on the previous day of sowing then the seeds air-dried for $15 \mathrm{hrs}$. until sowing time.

E) Control: The disinfected lupine seeds were soaked in sterilized water for 6 hours on the previous day of sowing then air-dried for $15 \mathrm{hrs}$. until sowing time. 


\section{Enumeration of bacterial and fungal popula- tions coated on seeds}

Enumeration of bacterium or fungus coated on seeds was performed by plate dilution method on the basis of colony-forming unit (CFU/seed) on nutrient yeast dextrose agar (NYDA) medium for $P$. polymyxa, or potato dextrose agar (PDA) supplemented with Rose bengal ( $25 \mathrm{mg} /$ /itre) for $T$. harzianum. Colony-forming units (CFU) were counted after 24 and 48 hrs of incubation for $P$. polymyxa and $T$. harzianum respectively (Rini and Sulochana, 2007). Population density of $P$. polymyxa were $4.1 \times 10^{5} ; 3.6 \times 10^{5}$ and $3.7 \times 10^{5} \mathrm{CFU}$ per seed of lupine and propagule density of $T$. harzianum were $4.3 \times 10^{4} ; 3.8 \times 10^{4}$ and $3.9 \times 10^{4} \mathrm{CFU}$ per seed of lupine in greenhouse experiment, field experiments and the experiment of oxidative enzymes activity determination, respectively.

\section{Greenhouse experiments}

The trials were carried out in the greenhouse of the Plant Pathology Research Institute, Agricultural Research Centre, Giza. Pots (30 cm in diameter) with a bottom drainage hole were sterilized by dipping in a $5 \%$ formalin solution for 15 minutes and left for one week till complete formalin evaporation. Pots were filled with steam disinfested sandy clay soil 1:2 (V/V). Soil infestation was achieved by mixing the inoculum of $R$. solani or $F$. oxysporum $\mathrm{f}$. $\mathrm{sp}$. lupini with the soil at the rate of $2 \%$ of soil weight (Papavizas \& Davey, 1962). Sterilized uninoculated grounded sorghum grains were added to the disinfested soil at the same rate for used as healthy control. The infested soil was mixed thoroughly and watered every 2 days for a week before planting to stimulate the fungal growth and ensure its distribution in the soil. Five $\mathrm{g}$ of Bradyrhizobium sp formulation (obtained from Biofertilizers Production Unit, Soils Water and Environment Res. Inst., (SWERI), Agric. Res. Centre (ARC), Giza, Egypt) were mixed in each pot during sowing. Five seeds of treated lupine seeds, as mentioned before, were sown in each pot and pots were irrigated directly. Ten replicated pots were used for each particular treatment. All pots were irrigated when necessary, and watered once a week to near field capacity with a $0.1 \% 15: 15: 15$ $(N: P: K)$ fertilizer solution in the first month and kept in a greenhouse under natural conditions. Other agricultural procedures were performed according to normal practice. The treatments were as follows: (1) Bion at $5 \mathrm{mM}$; (2) Salicylic acid at $5 \mathrm{mM}$; (3)
Saccharin at $3 \mathrm{mM}$; (4) P. polymyxa; (5) T. harzianum; (6) Rizolex-T.; (7) and (8) seeds soaking in water served as untreated control for both infested and non-infested soil. The damping-off disease incidence (DI) \%, percentage of wilt and disease severity index were determined as described below in Disease assessment. The experiment was repeated for determining the activity of oxidative enzymes and phenol content.

\section{Disease assessment}

\section{A) Damping-off disease}

The disease incidence (DI) \% was determined by recording pre-emergence damping-off and postemergence damping-off 15 and 30 days after sowing respectively according to the following formulas (Mona et al 2009):

\section{Pre-emergence \% Total No. of un-germinated seeds $x 100$ \\ $=$ Total No. of planted seeds \\ Post-emergence \% Total No. of rotted seedlings $x 100$ \\ $=$ Total No. of planted seeds \\ Survived seedlings $\%=$ \\ 100- (pre +post emergence)}

Reduction or increasing \% over the infected control was also calculated according to the following formula:

\section{Reduction or Increasing \% DI of Control - DI of treatment x100 \\ $=$

$$
\text { DI of Control }
$$

\section{B) Wilt disease}

Percentages of early and late wilt were recorded at 30 and 90 days after sowing, respectively.

\section{Disease incidence \% Number of wilted plants $\times 100$ \\ $=$ \\ Total Number of plants}

However, disease severity based on the foliar symptom was assessed 90 days after sowing using a scale of 0 to 4 , where: $0=$ healthy plant, all leaves green; 1 = lower leaves yellow; 2 = lower leaves wilted and some upper leaves yellow, exist- 
ence discoloration of vascular tissue; $3=$ whole leaves wilted, existence discoloration of vascular tissue; 4 = plant dead (Muslim et al 2003). The disease rating data was used to calculate disease severity index as DSI =

\section{$\left(0^{\star} n 1+1^{*} n 2+2^{*} n 3+3^{*} n 4+4^{\star} n 5\right) /\left(4^{*} N\right)^{*} 100$}

where $n 1-n 5$ are the number of plants in each disease category and $\mathrm{N}$ was the total number of plants.

\section{Field experiments}

The field experiments was carried out during the winter growing season 2016-2017 at two locations namely, Giza Agricultural Research Station, Giza Governorate and Ismailia Agricultural Research Station, Egypt, in field known to have root rot and wilt history, in order to investigate the effect of chemical and biotic inducers for controlling damping-off and wilt diseases. The disinfected lupine seeds were treated in the same manner in a greenhouse experiment. In the control treatment, seeds were soaked in distilled water as mentioned before. The treated lupine seeds were sown in the field on October 27, 2016, at Giza and Ismailia Governorate. The field trial (28 plots) was designed in complete randomized blocks with four replicates. The area of each plot was $10.5 \mathrm{~m}^{2}$ consisted of five rows; each row was $3.5 \mathrm{~m}$ length and $0.6 \mathrm{~m}$ width. All treatments were sown in hills 20 $\mathrm{cm}$ apart on both sides of the row ridge, with one seed per hill. Eight hundred grams of Bradyrhizobium formulation was mixed with approximately 50 $\mathrm{kg}$ of moistened fine sandy soil and added to field soil into the seed furrow during sowing, at the rate of $800 \mathrm{~g}$ Bradyrhizobium formulation/ feddan. All other recommended agricultural practices were followed according to the recommendations of the Egyptian Ministry of Agriculture and Land Reclamation. The treatments were as follows: (1) Bion at $5 \mathrm{mM}$ (2) Salicylic acid at $5 \mathrm{mM}$ (3) Saccharin at 3 $\mathrm{mM}$ (4) P. polymyxa (5) T. harzianum (6) Rizolex$\mathrm{T}$, and (7) Water (control). The damping-off disease incidence (DI) \% and the percentage of wilt were determined as mentioned before. Random samples of ten lupine plants were collected (from the inner rows) at harvest stage from each plot. Plant growth parameters of plant height $(\mathrm{cm})$, number of branches, number of pods per plant, the weight of one hundred seed and weight of seeds per plant were recorded as well as seed yield as ton/ feddan were calculated.
Effect of lupine seed treatments with different inducers on the activity of oxidative enzymes and phenol content

An experiment was carried out to determine the activity of oxidative enzymes and phenol content. Lupine plants were grown as mentioned before in the greenhouse experiment. Fifteen days after sowing, activity of peroxidase (PO), polyphenol oxidase (PPO) and phenol contents were determined in tissue extracts of soybean plants surviving from the following treatments: (1) Bion at $5 \mathrm{mM}$ (2) Salicylic acid at $5 \mathrm{mM} \mathrm{(3)} \mathrm{Saccharin} \mathrm{at} 3 \mathrm{mM}$ (4) P. polymyxa (5) T. harzianum (6) Water in infested soil (Control, infected) and (7) Water in noninfested soil (Control, healthy).

\section{Assay of enzymes activities}

\section{A) Assay of peroxidase (PO)}

The extraction and assay of peroxidase (PO) activity were carried out according to Chakraborty \& Chatterjee (2007).

\section{B) Assay of polyphenol oxidase (PPO)}

Extraction and assay of polyphenoloxidase enzyme (PPO) were carried out according to Sadasivam \& Manickam (1996).

\section{Determination of phenolic compounds}

Extraction of phenolic compounds was carried out according to Sutha et al (1998). However, phenolic compounds were determined using methods of analysis described by Snell \& Snell (1953). The total, free and conjugated phenolic contents were calculated on the basis of the calibration curve of catechol and expressed as catechol equivalents in milligrams per gram fresh weight.

\section{Statistical analysis}

Completely randomized design (CRD) and randomized blocks design (RBD) were conducted in greenhouse experiment and field experiment, respectively. The obtained data were subjected to computer statistical software (ASSISTAT) originated by Silva \& Azevedo (2009). Data analyzed using analysis of variance (ANOVA), and mean values were compared using Duncan's multiple range test at a significance level of $P \leq 0.05$. 


\section{RESULTS}

\section{1- Greenhouse experiment}

I- Effect of some inducers on the incidence of damping-off and wilt diseases of lupine

Results in Table (1) A \& B indicate that all treatments induced a significant reduction in the percentages of pre- and post-emergence dampingoff caused by $R$. solani or percentage of wilt caused by $F$. oxysporum f. sp. lupini compared to untreated infested control. Also, all treatments have significantly increased survived plants compared with untreated infested control. Bion, $T$. harzianum and Rizolex-T treatments gave the highest effect followed by each of $P$. Polymyxa and/or Salicylic acid treatments in the presence of $R$. solani and followed by Salicylic acid, P. polymyxa and $T$. harzianum in the presence $F$. oxysporum f. sp. Iupini. While the lowest reduction effect and lowest survived plants were attributed to Saccharin treatment.

However, all treatment reduced disease index of $F$. oxysporum f. sp. lupini, as Rizolex-T and Bion recorded the lowest values (8.0 and 9.0 respectively) as compared with untreated infested control (47). The rest treatments also reduced the wilt disease index with lower values (12-21).

Table 1. Effect of some chemical and biotic inducers as well as Rizolex-T as seed treatments on the percentage of damping-off and wilt diseases of lupine plants grown in artificially infested soil by Rhizoctonia solani (A) or Fusarium oxysporum f. sp. lupini (B) under greenhouse conditions

(A) R. solani

\begin{tabular}{|c|c|c|c|c|c|c|}
\hline \multirow{3}{*}{ Treatments } & \multicolumn{4}{|c|}{ Damping- off } & \multirow{3}{*}{$\begin{array}{c}\text { Survived plants } \\
\%\end{array}$} & \multirow{3}{*}{ Increasing \% } \\
\hline & \multicolumn{2}{|c|}{ Pre-emergence } & \multicolumn{2}{|c|}{ Post- emergence } & & \\
\hline & \begin{tabular}{|c|} 
Incidence \\
$\%$
\end{tabular} & \begin{tabular}{|c|} 
Reduction \\
$\%$
\end{tabular} & \begin{tabular}{|c|} 
Incidence \\
$\%$
\end{tabular} & \begin{tabular}{|c|} 
Reduction \\
$\%$
\end{tabular} & & \\
\hline Bion 5mM & $4.0 \mathrm{~b}$ & 87.5 & $4.0 a b$ & 66.7 & $92.0 \mathrm{a}$ & 64.30 \\
\hline Salicylic acid 5mM & $12.0 \mathrm{~b}$ & 62.5 & $0.0 \mathrm{~b}$ & 100.0 & $88.0 \mathrm{a}$ & 57.14 \\
\hline Saccharin $3 \mathrm{mM}$ & $12.0 \mathrm{~b}$ & 62.5 & $12.0 \mathrm{a}$ & 0.0 & $76.0 \mathrm{~b}$ & 35.71 \\
\hline P. polymyxa & $8.0 \mathrm{~b}$ & 75.0 & $4.0 \mathrm{ab}$ & 66.7 & $88.0 \mathrm{a}$ & 57.14 \\
\hline T. harzianum & $8.0 \mathrm{~b}$ & 75.0 & $0.0 \mathrm{~b}$ & 100.0 & $92.0 \mathrm{a}$ & 64.30 \\
\hline Rizolex -T & $4.0 \mathrm{~b}$ & 87.5 & $4.0 \mathrm{ab}$ & 66.7 & $92.0 \mathrm{a}$ & 64.30 \\
\hline $\begin{array}{c}\text { Control } \\
\text { (infested soil) }\end{array}$ & $32.0 \mathrm{a}$ & 0.0 & $12.0 \mathrm{a}$ & 0.0 & $56.0 \mathrm{c}$ & 0.0 \\
\hline $\begin{array}{l}\text { Control healthy } \\
\text { (non-infested soil) }\end{array}$ & \multicolumn{2}{|c|}{$4.0 \mathrm{~b}$} & \multicolumn{2}{|c|}{$0.0 \mathrm{~b}$} & \multicolumn{2}{|c|}{$96.0 \mathrm{a}$} \\
\hline
\end{tabular}

(B) F. oxysporum f. sp. Iupini

\begin{tabular}{|c|c|c|c|c|c|c|c|}
\hline \multirow{3}{*}{ Treatments } & \multicolumn{4}{|c|}{ Wilted plants $\%$} & \multirow{3}{*}{$\begin{array}{c}\text { Survived } \\
\text { plants } \\
\%\end{array}$} & \multirow{3}{*}{$\begin{array}{c}\text { Increasing } \\
\%\end{array}$} & \multirow{3}{*}{$\begin{array}{l}\text { Disease } \\
\text { index }\end{array}$} \\
\hline & \multicolumn{2}{|c|}{ After 30 days (Early) } & \multicolumn{2}{|c|}{ After 90 days (Late) } & & & \\
\hline & $\begin{array}{c}\text { Incidence } \\
\%\end{array}$ & $\begin{array}{c}\text { Reduction } \\
\%\end{array}$ & $\begin{array}{c}\text { Incidence } \\
\%\end{array}$ & \begin{tabular}{|c|} 
Reduction \\
$\%$
\end{tabular} & & & \\
\hline Bion 5mM & $4.0 \mathrm{~b}$ & 88.9 & $4.0 \mathrm{C}$ & 80.0 & $92.0 \mathrm{a}$ & 109.0 & 9.0 \\
\hline Salicylic acid 5mM & $8.0 \mathrm{~b}$ & 77.8 & $4.0 \mathrm{c}$ & 80.0 & $88.0 \mathrm{ab}$ & 100.0 & 12.0 \\
\hline Saccharin 3mM & $8.0 \mathrm{~b}$ & 77.8 & $12.0 \mathrm{~b}$ & 40.0 & $80.0 \mathrm{~b}$ & 81.8 & 21.0 \\
\hline P. polymyxa & $8.0 \mathrm{~b}$ & 77.8 & $4.0 \mathrm{c}$ & 80.0 & $88.0 \mathrm{ab}$ & 100.0 & 14.0 \\
\hline T. harzianum & $8.0 \mathrm{~b}$ & 77.8 & $4.0 \mathrm{C}$ & 80.0 & $88.0 \mathrm{ab}$ & 100.0 & 13.0 \\
\hline Rizolex -T & $4.0 \mathrm{~b}$ & 88.9 & $4.0 \mathrm{C}$ & 80.0 & $92.0 \mathrm{a}$ & 109.0 & 8.0 \\
\hline $\begin{array}{c}\text { Control } \\
\text { (infested soil) }\end{array}$ & 36.0 a & 0.0 & 20.0 a & 0.0 & $44.0 \mathrm{c}$ & 0.0 & 47.0 \\
\hline $\begin{array}{l}\text { Control healthy } \\
\text { (non-infested } \\
\text { soil) }\end{array}$ & \multicolumn{2}{|c|}{$2.0 \mathrm{~b}$} & \multicolumn{2}{|c|}{$4.0 \mathrm{c}$} & \multicolumn{2}{|c|}{$94.0 \mathrm{a}$} & 2.0 \\
\hline
\end{tabular}

Means in each column followed by the same letter are not significantly different according to Duncan's multiple range test, $(p=0.05)$. 


\section{2- Field experiments}

I- Effect of some inducers on the incidence of damping-off and wilt diseases of lupine

Results in Table 2 (A\&B) exhibited that all the inducers have significantly reduced the percentages of pre-emergence damping-off and percentage of wilted lupine plants as compared with untreated control in two locations i.e., Giza and
Ismailia, such results were concomitant with significant increases survived lupine plants treated with inducers over the untreated control. As for treatments, Rizolex-T and Bion gave the highest values in reducing diseases as well as increasing the survived lupine plants compared with other treatments. On the other hand, Saccharin resulted in the lowest values even in decreasing diseases or increasing survival.

Table 2. Effect of some chemical and biotic inducers as well as Rizolex-T as seed treatments on the percentage of damping-off and wilt diseases of lupine plants grown under field conditions at Giza Agricultural Research Station (A) and Ismailia Agricultural Research Station (B) during winter growing season 2016 2017 (natural infection)

\section{(A): Giza Agricultural Research Station}

\begin{tabular}{|c|c|c|c|c|c|c|c|}
\hline \multirow{3}{*}{ Treatments } & \multicolumn{4}{|c|}{ Damping- off } & \multirow{3}{*}{$\begin{array}{c}\text { Wilted } \\
\text { plants } \\
\%\end{array}$} & \multirow{3}{*}{$\begin{array}{c}\text { Survived } \\
\text { plants } \\
\%\end{array}$} & \multirow{3}{*}{$\begin{array}{c}\text { Increasing } \\
\%\end{array}$} \\
\hline & \multicolumn{2}{|c|}{ Pre-emergence } & \multicolumn{2}{|c|}{ Post- emergence } & & & \\
\hline & $\begin{array}{c}\text { Incidence } \\
\%\end{array}$ & $\begin{array}{c}\text { Reduction } \\
\%\end{array}$ & $\begin{array}{c}\text { Incidence } \\
\%\end{array}$ & $\begin{array}{c}\text { Reduction } \\
\%\end{array}$ & & & \\
\hline Bion 5mM & $18.7 \mathrm{c}$ & 54.8 & $4.0 \mathrm{ab}$ & 45.2 & $2.5 \mathrm{~cd}$ & $74.8 \mathrm{ab}$ & 114.9 \\
\hline Salicylic acid 5mM & 24.2 bc & 41.5 & $4.7 \mathrm{a}$ & 35.6 & $3.3 \mathrm{bcd}$ & $67.8 \mathrm{bcd}$ & 94.8 \\
\hline Saccharin 3mM & $27.0 \mathrm{~b}$ & 34.8 & $7.0 \mathrm{a}$ & 4.1 & $4.1 \mathrm{~b}$ & $61.5 \mathrm{~d}$ & 77.8 \\
\hline P. polymyxa & $21.3 \mathrm{bc}$ & 48.6 & $6.0 \mathrm{a}$ & 17.8 & $2.3 \mathrm{~cd}$ & $70.4 \mathrm{abc}$ & 108.1 \\
\hline T. harzianum & $25.5 \mathrm{bc}$ & 38.6 & $6.2 \mathrm{a}$ & 15.1 & $3.8 \mathrm{bc}$ & $64.5 \mathrm{~cd}$ & 85.3 \\
\hline Rizolex -T & $18.8 \mathrm{c}$ & 54.6 & $1.8 \mathrm{~b}$ & 75.3 & $2.0 \mathrm{~d}$ & $77.4 \mathrm{a}$ & 122.1 \\
\hline Control & $41.4 \mathrm{a}$ & - & $7.3 \mathrm{a}$ & - & $16.5 \mathrm{a}$ & $34.8 \mathrm{e}$ & - \\
\hline
\end{tabular}

(B): Ismailia Agricultural Research Station

\begin{tabular}{|c|c|c|c|c|c|c|c|}
\hline \multirow{3}{*}{ Treatments } & \multicolumn{4}{|c|}{ Damping- off } & \multirow{3}{*}{$\begin{array}{c}\text { Wilted } \\
\text { plants } \\
\%\end{array}$} & \multirow{3}{*}{$\begin{array}{c}\text { Survived } \\
\text { plants } \\
\%\end{array}$} & \multirow{3}{*}{$\begin{array}{c}\text { Increasing } \\
\%\end{array}$} \\
\hline & \multicolumn{2}{|c|}{ Pre-emergence } & \multicolumn{2}{|c|}{ Post- emergence } & & & \\
\hline & \begin{tabular}{|c|} 
Incidence \\
$\%$
\end{tabular} & \begin{tabular}{|c}
$\begin{array}{c}\text { Reduction } \\
\%\end{array}$ \\
\end{tabular} & \begin{tabular}{|c} 
Incidence \\
$\%$ \\
\end{tabular} & \begin{tabular}{|c|} 
Reduction \\
$\%$ \\
\end{tabular} & & & \\
\hline Bion 5mM & $17.9 \mathrm{c}$ & 55.1 & $3.8 \mathrm{ab}$ & 47.2 & $2.7 \mathrm{~cd}$ & $75.6 \mathrm{ab}$ & 112.3 \\
\hline Salicylic acid 5mM & $22.3 \mathrm{bc}$ & 44.1 & $4.1 \mathrm{ab}$ & 43.1 & $4.1 \quad b$ & $69.5 \mathrm{bc}$ & 95.2 \\
\hline Saccharin 3mM & $25.1 \mathrm{~b}$ & 37.1 & $6.4 \mathrm{a}$ & 11.1 & $4.5 \mathrm{~b}$ & $64.0 \mathrm{c}$ & 79.8 \\
\hline P. polymyxa & $19.8 \mathrm{bc}$ & 50.4 & $5.8 \mathrm{a}$ & 19.4 & $2.1 \mathrm{~d}$ & $72.3 \mathrm{ab}$ & 103.1 \\
\hline T. harzianum & $20.3 \mathrm{bc}$ & 49.1 & $6.2 \mathrm{a}$ & 86.1 & $3.3 \mathrm{bc}$ & $70.2 \mathrm{bc}$ & 97.2 \\
\hline Rizolex -T & $16.1 \mathrm{c}$ & 59.6 & $1.5 \mathrm{~b}$ & 79.2 & $2.4 \mathrm{~cd}$ & $80.0 \mathrm{a}$ & 124.7 \\
\hline Control & 39.9 a & - & $7.2 \mathrm{a}$ & - & $17.3 \mathrm{a}$ & $35.6 \mathrm{~d}$ & - \\
\hline
\end{tabular}

Means in each column followed by the same letter are not significantly different according to Duncan's multiple range test, $(p=0.05)$.

\section{II- Effect of some inducers on growth parame- ters and yield of lupine plants}

Under field conditions, inducers treatments significantly improved growth parameters and yield compared with untreated control in the two locations (Table 3, A \& B).

\section{Plant height}

In two locations, all treatments significantly increased plant height as compared with untreated control. The maximum plant height was recorded with Bion, Salicylic acid and Rizolex-T treatments at Giza followed by $P$. polymyxa and salicylic acid 
treatments. At Ismailia, the maximum plant height was recorded with Rizolex-T and Bion treatment. However, in two locations there were no significant differences between the treatments with Saccharin and T. harzianum.

\section{Number of branches per plant}

In two locations, the highest significant increase in the number of branches per lupine plants was recorded with Bion, Rizolex-T and P. Polymyxa treatments followed by salicylic acid and $T$. harzianum treatments at Giza and followed by $T$. harzianum and salicylic acid treatments at Ismailia Agricultural Research Station.

\section{Number of pods per plant}

The number of pods per plant significantly increased with all treatments as compared with untreated control. At Giza Agricultural Research Station the maximum number of pods per plant was recorded with Bion and Rizolex-T treatments, while the minimum number of pods per plant was recorded with $T$. harzianum treatment. In Ismailia, the maximum effect was observed with Rizolex-T and Bion treatments.

\section{Seed weight per plant}

In the two locations, all treatments significantly increased seed weight per plant as compared with untreated control. At Giza Agricultural Research Station, the maximum seed weight per plant was recorded with Bion treatment followed by Rizolex-T and salicylic acid. Meantime, there was no significant difference among other treatments.

At Ismailia Agricultural Research Station, the maximum seed weight per plant was recorded with Rizolex-T, Bion followed by salicylic acid treatments. Meantime, there were no significant differences between the treatments of $P$. polymyxa and $T$. harzianum in the two locations.

\section{The weight of one hundred seed}

In the two locations, all treatments significantly increased the weight of one hundred seed as compared with untreated control. Rizolex-T and Bion significantly increased the weight of one hundred seed with a varied trend from the rest of treatments followed by salicylic acid, $T$. harzianum and $P$. polymyxa treatments at Giza and salicylic acid and $P$. polymyxa treatments at Ismailia.

Table 3. Effect of some chemical and biotic inducers as well as Rizolex-T as seed treatments on some growth parameters of lupine plants grown under field conditions at Giza Agricultural Research Station (A) and Ismailia Agricultural Research Station (B) during winter growing season 2016 - 2017 (natural infection)

(A): Giza Agricultural Research Station

\begin{tabular}{|c|c|c|c|c|c|c|}
\hline Treatments & $\begin{array}{l}\text { Plant height } \\
\text { (cm) }\end{array}$ & $\begin{array}{c}\text { Number of } \\
\text { branches/ } \\
\text { plant }\end{array}$ & $\begin{array}{c}\text { Number } \\
\text { of pods/ } \\
\text { plant }\end{array}$ & $\begin{array}{c}\text { Seed } \\
\text { weight / } \\
\text { Plant (g) }\end{array}$ & $\begin{array}{c}100 \text { seed } \\
\text { weight } \\
(\mathrm{g})\end{array}$ & $\begin{array}{c}\text { Seed yield } \\
\text { (ton/fed) }\end{array}$ \\
\hline Bion $5 \mathrm{mM}$ & $132.25 \mathrm{a}$ & $6.50 \mathrm{a}$ & $36.25 \mathrm{a}$ & $42.30 \mathrm{a}$ & $41 \mathrm{a}$ & $2.115 \mathrm{a}$ \\
\hline Salicylic acid 5mM & $129.75 a b$ & $5.72 \mathrm{~b}$ & $32.95 \mathrm{a}$ & $38.3 a b$ & $37.2 \mathrm{~b}$ & $1.998 a b$ \\
\hline Saccharin 3mM & $119.25 \mathrm{c}$ & $5.10 \mathrm{c}$ & $30.55 \mathrm{a}$ & $30.2 \mathrm{~b}$ & $33.2 \mathrm{c}$ & $1.587 \mathrm{~d}$ \\
\hline P. polymyxa & $125.25 b$ & $5.93 \mathrm{~b}$ & $33.25 \mathrm{a}$ & $31.2 \mathrm{~b}$ & $34.3 \mathrm{bc}$ & $1.873 \mathrm{bc}$ \\
\hline T. harzianum & $116.25 \mathrm{c}$ & $5.50 \mathrm{bc}$ & $27.9 \mathrm{a}$ & $33.75 \mathrm{~b}$ & $35.5 \mathrm{bc}$ & $1.705 \mathrm{~cd}$ \\
\hline Rizolex -T & $129.25 a b$ & $5.93 \mathrm{~b}$ & $34.5 \mathrm{a}$ & $43.1 \mathrm{a}$ & $41.5 \mathrm{a}$ & $2.019 a b$ \\
\hline Control & $107.98 \mathrm{~d}$ & $4.20 \mathrm{~d}$ & $15 \mathrm{~b}$ & $23.25 \mathrm{c}$ & $29.4 \mathrm{~d}$ & $1.183 \mathrm{e}$ \\
\hline
\end{tabular}


(B): Ismailia Agricultural Research Station

\begin{tabular}{|c|c|c|c|c|c|c|}
\hline Treatments & $\begin{array}{l}\text { Plant height } \\
\text { (cm) }\end{array}$ & $\begin{array}{c}\text { Number of } \\
\text { branches/ } \\
\text { plant }\end{array}$ & $\begin{array}{l}\text { Number of } \\
\text { pods/ plant }\end{array}$ & $\begin{array}{c}\text { Seed } \\
\text { weight } / \\
\text { Plant (g) }\end{array}$ & $\begin{array}{c}100 \text { seed } \\
\text { weight }(g)\end{array}$ & $\begin{array}{c}\text { Seed } \\
\text { yield } \\
\text { (ton/fed) }\end{array}$ \\
\hline Bion 5mM & $128 \mathrm{a}$ & $6.43 \mathrm{a}$ & $34.85 a b$ & $38.1 \mathrm{a}$ & $37.3 \mathrm{~b}$ & $1.752 a b$ \\
\hline Salicylic acid $5 \mathrm{mM}$ & $122.5 \mathrm{ab}$ & $5.65 \mathrm{~b}$ & $33.1 \mathrm{abc}$ & $34.43 \mathrm{~b}$ & $34.65 \mathrm{bc}$ & $1.599 \mathrm{bc}$ \\
\hline Saccharin 3mM & $118 b$ & $5.07 \mathrm{c}$ & $28.85 \mathrm{c}$ & $29.8 \mathrm{c}$ & $32.75 \mathrm{c}$ & $1.419 \mathrm{c}$ \\
\hline P. polymyxa & $123.9 a b$ & $6.1 \mathrm{ab}$ & $32.93 \mathrm{bc}$ & $33.1 \mathrm{~b}$ & $34.1 \mathrm{bc}$ & $1.561 \mathrm{bc}$ \\
\hline T. harzianum & $117.9 \mathrm{~b}$ & $5.65 \mathrm{~b}$ & $30.8 \mathrm{bc}$ & $32.15 \mathrm{~b}$ & $32.3 \mathrm{c}$ & $1.458 \mathrm{c}$ \\
\hline Rizolex $-T$ & $128.6 \mathrm{a}$ & $6.1 \mathrm{ab}$ & $36.55 \mathrm{a}$ & 39 & $40.1 \mathrm{a}$ & $1.880 \mathrm{a}$ \\
\hline Control & $109.3 \mathrm{C}$ & $4.35 \mathrm{~d}$ & $17.8 \mathrm{~d}$ & $21 d$ & $27.6 \mathrm{~d}$ & $0.844 d$ \\
\hline
\end{tabular}

Means in each column followed by the same letter are not significantly different according to Duncan's multiple range test, $(p=0.05)$.

\section{Seed yield}

The two locations showed nearly similar results which indicated that all treatments significantly increased the seed yield as compared with untreated control. At Giza and Ismailia, the maximum seed yield was recorded from the Bion, Rizolex-T with no significant differences, followed by salicylic acid and $P$. polymyxa treatments. Whereas, the lowest seed yield values compared with untreated control were recorded in Saccharin treatment at Giza and Ismailia Agricultural Research Stations.

\section{3- Effect of Lupine seed treatments with differ-} ent inducers on the activity of oxidative enzymes and phenol content

\section{I- Activity of oxidative enzymes}

Activities of peroxidase (PO) and polyphenol oxidase (PPO) enzymes of lupine plants were evaluated with the different inducer treatments in the presence of $R$. solani (Table 4 A) or F. oxysporum f. sp. lupini (Table 4 B). Results showed that all treatments were effective in increasing enzyme activities. The highest increase of $\mathrm{PO}$ and PPO activities as compared to the untreated control was achieved with Bion treatment either in the presence of $R$. solani or $F$. oxysporum f. sp. lupini. Meantime, the salicylic acid treatment showed a considerable increase in the two enzymes followed by $P$. polymyxa and $T$. harzianum treatments. However, the lowest activity of the enzymes was obtained when Saccharin was applied. However, Results showed that clear higher values of $\mathrm{PO}$ activity than PPO activity in all treatments in the presence of two pathogens. In addition, the per- centage of increase in enzyme activity as induced by inducers treatments presented clear higher values of PPO than PO in all treatments; such a trend was true with the two pathogens. Meanwhile, it has to notice that infestation with the two fungal pathogens in the absence of inducers, clearly increased the activity of both PPO and PO than that recorded in healthy untreated plants as blank of all treatments.

\section{II- Phenol content}

The content of total phenols coincided with the trend of data of both PO and PPO enzymes, where it was highly enhanced in lupine plants treated with different inducers compared with untreated plants in the presence of $R$. solani (Table 5A) or F. oxysporum f. sp. lupini (Table 5B). The maximum increase in the content of total phenolic compounds was recorded with Bion treatment followed by salicylic acid and $P$. polymyxa compared with untreated control. Whereas the less increases in total phenols content were recognized when Saccharin was applied. As for conjugated phenols, salicylic acid and Bion treatments gave the highest increase over untreated control followed by $P$. polymyxa. Whereas the less increases were recognized in the conjugated phenols when $T$. harzianum and Saccharin were applied. Moreover, the least values in total, free and conjugated phenols were recorded in the healthy control treatment, indicating the role of pathogens in raising the phenol content of the host plant. On the other hand, free phenols represented the highest figures of phenolic compounds than the conjugated phenols in all treatments as well as control untreated plants. 
Table 4. Effect of some chemical and biotic inducers as seed treatments on the peroxidase and polyphenol oxidase activity in lupine plants grown in artificially infested soil by Rhizoctonia solani (A) or Fusarium oxysporum f. sp. lupini (B) under greenhouse conditions

(A) R. solani

\begin{tabular}{|c|c|c|c|c|}
\hline \multirow[t]{2}{*}{ Treatments } & \multicolumn{2}{|c|}{$\begin{array}{c}\text { Peroxidase activity } \\
\text { (absorbance at } 430 \mathrm{~nm} \text { ) } \\
\text { (Enzyme unit } / \mathrm{mg} \text { protein } / \mathrm{min} \text { ) }\end{array}$} & \multicolumn{2}{|c|}{$\begin{array}{l}\text { Polyphenol oxidase activity } \\
\text { (absorbance at } 495 \mathrm{~nm} \text { ) } \\
\text { (Enzyme unit/mg protein/min) }\end{array}$} \\
\hline & Activity & $\begin{array}{c}\text { Increasing over } \\
\text { control \% }\end{array}$ & Activity & $\begin{array}{l}\text { Increasing over } \\
\text { control \% }\end{array}$ \\
\hline Bion $5 \mathrm{mM}$ & 0.322 & 131.4 & 0.075 & 294.7 \\
\hline Salicylic acid $5 \mathrm{mM}$ & 0.291 & 109.4 & 0.071 & 273.7 \\
\hline Saccharin $3 \mathrm{mM}$ & 0.213 & 53.2 & 0.061 & 221.1 \\
\hline P. polymyxa & 0.280 & 101.4 & 0.070 & 268.4 \\
\hline T. harzianum & 0.232 & 66.9 & 0.059 & 210.5 \\
\hline Control (infested soil) & 0.139 & - & 0.019 & - \\
\hline $\begin{array}{c}\text { Control healthy } \\
\text { (non-infested soil) }\end{array}$ & \multicolumn{2}{|c|}{0.121} & \multicolumn{2}{|c|}{0.010} \\
\hline
\end{tabular}

(B) F. oxysporum f. sp. lupini

\begin{tabular}{|c|c|c|c|c|}
\hline \multirow[t]{2}{*}{ Treatments } & \multicolumn{2}{|c|}{$\begin{array}{c}\text { Peroxidase activity } \\
\text { (absorbance at } 430 \mathrm{~nm} \text { ) } \\
\text { (Enzyme unit/mg protein } / \mathrm{min} \text { ) }\end{array}$} & \multicolumn{2}{|c|}{$\begin{array}{l}\text { Polyphenol oxidase activity } \\
\text { (absorbance at } 495 \mathrm{~nm} \text { ) } \\
\text { (Enzyme unit/mg protein/min) }\end{array}$} \\
\hline & Activity & $\begin{array}{l}\text { Increasing over } \\
\text { control \% }\end{array}$ & Activity & $\begin{array}{l}\text { Increasing over } \\
\text { control \% }\end{array}$ \\
\hline Bion $5 \mathrm{mM}$ & 0.401 & 184.4 & 0.069 & 200.0 \\
\hline Salicylic acid $5 \mathrm{mM}$ & 0.298 & 111.3 & 0.067 & 191.3 \\
\hline Saccharin $3 \mathrm{mM}$ & 0.223 & 58.2 & 0.059 & 156.5 \\
\hline P. polymyxa & 0.291 & 105.4 & 0.065 & 182.6 \\
\hline T. harzianum & 0.256 & 81.6 & 0.052 & 126.1 \\
\hline Control (infested soil) & 0.141 & - & 0.023 & - \\
\hline $\begin{array}{c}\text { Control healthy } \\
\text { (non-infested soil) }\end{array}$ & \multicolumn{2}{|c|}{0.121} & \multicolumn{2}{|c|}{0.010} \\
\hline
\end{tabular}

Table 5. Effect of some chemical and biotic inducers as seed treatments on levels of phenolic compounds in lupine plants grown in artificially infested soil by Rhizoctonia solani (A) or Fusarium oxysporum f. sp. lupini (B) under greenhouse conditions

\section{(A) R. solani:}

\begin{tabular}{|c|c|c|c|c|c|c|}
\hline \multirow[b]{2}{*}{ Treatments } & \multicolumn{6}{|c|}{ Phenolic contents (catechol equivalents $\mathrm{mg} / \mathrm{g}$ fresh weight) } \\
\hline & $\begin{array}{c}\text { Total } \\
\text { phenols }\end{array}$ & $\begin{array}{l}\text { Increase } \\
\text { over } \\
\text { control \% }\end{array}$ & $\begin{array}{c}\text { Free } \\
\text { phenols }\end{array}$ & $\begin{array}{c}\text { Increase over } \\
\text { control } \%\end{array}$ & $\begin{array}{c}\text { Conjugated } \\
\text { phenols }\end{array}$ & $\begin{array}{c}\text { Increase } \\
\text { over control } \\
\%\end{array}$ \\
\hline Bion $5 \mathrm{mM}$ & 8.66 & 84.65 & 6.91 & 100.87 & 1.75 & 38.9 \\
\hline Salicylic acid $5 \mathrm{mM}$ & 7.71 & 64.40 & 5.91 & 71.80 & 1.80 & 42.9 \\
\hline Saccharin $3 \mathrm{mM}$ & 5.77 & 23.00 & 4.43 & 28.70 & 1.34 & 6.3 \\
\hline P. polymyxa & 6.66 & 42.00 & 4.97 & 44.50 & 1.69 & 34.2 \\
\hline T. harzianum & 5.87 & 25.20 & 4.55 & 61.33 & 1.32 & 4.8 \\
\hline Control (infested soil) & 4.69 & 0.00 & 3.44 & 0.00 & 1.26 & 0.0 \\
\hline $\begin{array}{l}\text { Control healthy } \\
\text { (non infested soil) }\end{array}$ & \multicolumn{2}{|c|}{2.85} & \multicolumn{2}{|r|}{2.10} & \multicolumn{2}{|c|}{0.75} \\
\hline
\end{tabular}


(B) F. oxysporum f. sp. Iupini:

\begin{tabular}{|c|c|c|c|c|c|c|}
\hline \multirow{2}{*}{ Treatments } & \multicolumn{6}{|c|}{ Phenolic contents (catechol equivalents $\mathbf{~ m g / g}$ fresh weight) } \\
\cline { 2 - 7 } & $\begin{array}{c}\text { Total } \\
\text { phenols }\end{array}$ & $\begin{array}{c}\text { Increase } \\
\text { over } \\
\text { control \% }\end{array}$ & $\begin{array}{c}\text { Free } \\
\text { phenols }\end{array}$ & $\begin{array}{c}\text { Increase } \\
\text { over } \\
\text { control \% }\end{array}$ & $\begin{array}{c}\text { Conjugated } \\
\text { phenols }\end{array}$ & $\begin{array}{c}\text { Increase over } \\
\text { control \% }\end{array}$ \\
\hline Bion 5 mM & 7.21 & 39.7 & 5.36 & 39.6 & 1.85 & 40.2 \\
Salicylic acid 5 mM & 6.91 & 33.9 & 4.23 & 10.1 & 2.68 & 103.0 \\
Saccharin 3 mM & 5.81 & 12.59 & 4.11 & 7.03 & 1.70 & 28.7 \\
P. polymyxa & 6.29 & 21.9 & 4.58 & 19.3 & 1.71 & 29.5 \\
T. harzianum & 6.12 & 18.6 & 4.57 & 19.0 & 1.55 & 17.4 \\
\hline $\begin{array}{c}\text { Control (infested } \\
\text { soil) }\end{array}$ & $\mathbf{5 . 1 6}$ & $\mathbf{0 . 0}$ & $\mathbf{3 . 8 4}$ & $\mathbf{0 . 0}$ & $\mathbf{1 . 3 2}$ & $\mathbf{0 . 0}$ \\
\hline $\begin{array}{c}\text { Control healthy } \\
\text { (non infested soil) }\end{array}$ & $\mathbf{2 . 8 5}$ & & $\mathbf{2 . 1 0}$ & & $\mathbf{0 . 7 5}$ \\
\hline
\end{tabular}

\section{DISCUSSION}

In Egypt, lupine is one of the preferable hosts to Rhizoctonia solani and F. oxysporum f.sp. lupini causing damping-off and wilt diseases respectively (Zian, 2011; Abdel-Monaim et al 2016; El-Sayed and Abdel- Monaim, 2017).

As recorded till now, the management of such two diseases has conventionally depended on chemical application. So, recent research priorities embraced disease control programs that are compatible with sustainable agriculture.

Acquired and induced resistance against future pathogen attacks, seem to be one of the safe alternatives to decrease the use of fungicides. Resistance induced by these inducers has a broad spectrum against many pathogens and longlasting, but rarely provides complete control of infection, as many resistance elicitors provide between 20 and $85 \%$ disease control. (Walters et al 2013; Burketova et al 2015; Hartman et al 2016; and Kannojia et al 2019).

In the present work, lupine seed treatments with Bion [benzothiadiazole, (BTH)], salicylic acid (SA) and saccharin as chemical inducers resulted in a significant reduction of damping-off and wilt diseases, and highly increased growth parameters as well as the net seeds yield. These results were obtained from the greenhouse experiment and confirmed by field experiments data. Such results were consistent with those reported on lupine plants by (Ali et al 2009; Abdel-Monaim et al 2012; Marwa et al 2014). A comparative evaluation showed that the tested chemical inducers differed in their effectiveness against lupine dampingoff and wilt diseases. Bion and salicylic acid were the most effective treatments; they increased survived lupine plants under field conditions by $114.8 \%$ and $94.7 \%$, respectively, in Giza Governorate and by $112.4 \%$ and $95.2 \%$, respectively, in Ismailia Governorate.

In this respect, Benzothiadiazole (BTH) was widely reported to induce plant resistance against a broad spectrum of pathogens in many plant species (Walters et al 2013), for example in pea against Uromyces pisi (Barilli et al 2010); in faba bean against Uromyces viciae-fabae (Sillero et al 2012); and in sunflower against Sclerotinia sclerotiorum (Bán et al 2017). Early, BTH was shown to induce expression of systemic acquired resistance "SAR" genes (Gorlach et al 1996 and Friedrich et al 1996). The mechanisms of BTH as inducer have been shown to involve in the activation of SAR mechanisms based on the SA pathway (Friedrich et al 1996), with consequent upregulation of defense genes (Bovie et al 2004) and accumulation of phenolic compounds (Iriti et al 2004); also, activating resistance by increasing the activity of peroxidase enzyme (Sarma et al 2007) and the accumulation of pathogenesis-related (PR) proteins, some of which have antimicrobial properties (Sauerborn et al 2002).

Salicylic acid as a key of plant hormone plays an important role in the induction of plant defense against a variety of biotic and abiotic stresses through morphological, physiological and biochemical mechanisms (Kumar, 2014). It was declared to induce resistance against many pathogens in many plant species for example in guar against Rhizoctonia solani (Abdel-Monaim, 2016); in snap bean against Rhizoctonia solani (Ahmed, 2016); and in lupine against Fusarium solani, Rhizoctonia 
solani and Macrophomina phaseolina (El-Sayed and Abdel-Monaim, 2017). Treatment with SA and its derivatives induced the expression of pathogenesis-related (PR) proteins (Gaffney et al 1993). It regulates the activities of various enzymes such as, peroxidase (PO), polyphenol oxidase (PPO), phenylalanine ammonia-lyase (PAL), etc., which are the major components of induced plant defense against biotic and abiotic stresses (Idrees et al 2011).

However, saccharin as seed soaking treatment gave the least reduction of the disease incidence among the chemical inducers. Meanwhile, saccharin has been found to induce systemic resistance against several diseases as a foliar application or root drench: tobacco mosaic virus (TMV) in tobacco, Colletotrichum lagenariumin in cucumber, and Uromyces appendiculatus in runner bean (Siegrist et al 1998); $R$. solani in soybean (Marwa et al 2014). Additionally, probenazole (ORYZEMATE), of which saccharin is a metabolite, is used mainly on rice and was effective in controlling bacterial blight caused by Xanthomonas oryzae and rice blast caused by Magnaporthe grisea (Oostendorp et al 2001). Srivastava et al (2011) found that saccharin applied as a root drench to soybean plants was usually more effective than the leaf treatment at inducing protection. A similar response has been observed by other researchers in other plant species (Boyle \& Walters, 2005\& 2006).

As for biotic inducers tested i.e., P. polymyxa and $T$. harzianum, tended in the same as chemical inducers, in limiting the development of both diseases (damping-off and wilt) of lupine, but their effect still lower than that of bion. To some extent, there were no significant differences between the two bio-inducers used. Previous reports have shown that $P$. polymyxa and $T$. harzianum control the development of many soil-borne pathogens i.e. $R$. solani and Fusarium spp. on many crops under greenhouse and field conditions (Marwa et al 2014; Sarhan and Shehata 2014; Raza et al 2015 and Redda et al 2018).

The bacterium $P$. polymyxa is known for its ability to produce antimicrobial compounds (produced by some strains) act against fungi, bacteria, and actinomycetes including gavaserin and saltavidin (Pichard et al 1995); fusaricidins (Beatty \& Jensen, 2002); polymyxins and lantibiotics (He et al 2007). Plant growth promotion may be an indirect effect of this antibiotic production through the suppression of plant diseases in disease-carrying soil. One of the possible explanations for growth promotion by $P$. polymyxa which has also been reported that it produces many plant growth stimulators, including auxin as indole-3-acetic acid (da Mota et al 2008) and cytokinin (Timmusk et al 1999). So, the application of $P$. polymyxa in seed pelleting can be used to manage pre- and postemergence damping-off in plants (Choong-Min et al 2006).

However, the genus Trichoderma has been known since at least the 1920s for its ability to act as biocontrol agents against plant pathogens (Samuels, 1996). T. harzianum was established to be an effective producer of many extracellular enzymes and some of these are involved in the biological control of plant diseases (Almeida et al 2007). Some Trichoderma biological control agents (BCAs) produce highly efficient siderophores that chelate iron and stop the growth of other fungi (Chet and Inbar, 1994). Substantial information provides the support that the extraordinary capacity of $T$. harzianum to attack the structures of phytopathogenic fungi and sclerotial degradation by mycoparasitism which has been observed for $R$. solani (Almeida et al 2007). Meanwhile, T. harzianum is well-known producer of antibiotic (produced by some strains) that are toxic for phytopathogenic fungi, including Koninginins $A, B, D, E$ and G (Almassi et al 1991; Ghisalberti \& Rowland, 1993); Harzianopyridone, Harzianic acid, Azaphilones and Harzianolide (Vinale et al 2006; 2009); and Trichorzianines A (ElHajji et al 1987).

Also, some Trichoderma strains that produce cytokinin-like molecules, e.g. zeatyn and gibberellin GA3 or GA3-related, have been detected (Benitez et al 2004). Furthermore, during plant- Trichoderma interaction, numerous elicitors released by the Trichoderma hyphae may induce different types of signals transmitted within the plant e.g. by salicylic acid (SA), jasmonic acid (JA) or reactive oxygen species (ROS), triggering expression of defense proteins which refers to the induction of resistance. As a result of gene activation, the plant produces enzymes involved in direct suppression of pathogens and enhancing the biochemical and structural barriers in a plant. Depending on the Trichoderma isolate, plant cultivar and conditions, the defensive reactions activated by the fungi may fluctuate between the two types of systemic resistance i.e. induced systemic resistance and systemic acquired resistance (Harman et al 2004; Nawrocka \& Małolepsza, 2013).

However, the treatments with Bion, SA, P. Polymyxa and $T$. harzianum as seed treatments were effective in eliciting the enzyme activities (peroxi- 
dase, PO and polyphenol oxidase, PPO) in the presence of $R$. solani or F. oxysporum f.sp. lupini and the maximum activities of the two enzymes were observed with Bion treatment. The increase in activity was related to increased plant resistance against infection by many diseases (Wang et al 2000). In this respect, both biotic and chemical inducers are known to have eliciting activities leading to a variety of defense reactions in host plants in response to microbial infection, including the accumulation of pathogenesis-related PR- proteins and defense-related enzymes (Nafie and Mazen 2008; Mandal et al 2009).

The oxidation of phenols is mediated by the enzymes PO and PPO and the resulting quinones are effective inhibitors of $\mathrm{SH}$ group of enzymes which may inhibit the pathogen (Goodman et al 1967). Peroxidase is reported to have an important function in secondary cell wall biosynthesis (Grisebach, 1981). Therefore, Peroxidase may be directly associated with the increased ability of protected tissue for lignification which may restrict the penetration (Gross, 1979). Meantime, polyphenol oxidase (PPO) is capable of dehydrogenating of o-diphenols to produce o-quinones (antimicrobial compounds) as well as lignification of plant cells during microbial invasion (Meyer, 1987).

Furthermore, the treatments led to increasing of the phenolic compounds content compared with the untreated control. Such an increase was highly obvious with free phenols compared with conjugated. In this regard, the role of phenolic compounds in disease resistance was postulated by Nicholson and Hammerschmidt (1992). They indicated that phenols are oxidized to quinones or semi-quinones which are more toxic and play a great role as antimicrobial substances on the fungal pathogens (Farkas and Kiraly 1962). So, it can be concluded that treatments with Bion, salicylic acid, P. Polymyxa, and T. harzianum as seed treatments increased plant resistance against the infection by $R$. solani, or F. oxysporum f.sp. lupini improved plant growth and yield. Such treatments may be used as a part of integrated disease management for field crops in order to avoid the use of fungicides.

\section{REFERENCE}

Abdel-Monaim M.F. 2016. Salicylic acid and Pseudomonas fluorescens as safe control means against Rhizoctonia solani in guar ( $\mathrm{Cy}$ amopsis tetragonoloba (L.) Taub.). Egypt. J. Phytopathol., 44, 25-47.
Abdel-Monaim M.F., Ismail M.E. and Morsy K.M. 2012. Induction of Systematic Resistance in Soybean Plants against Fusarium Wilt Disease by Seed Treatment with Benzothiadiazole and Humic. African J. of Biotechnology, 11, 24542465.

Abdel-Monaim M.F., Mazen M.M. and Atwa M.A.M. 2016. Effect of cyanobacteria on reducing damping-off and root rot incidence in lupine plants, New Valley Governorate, Egypt. British Microbiology Research J. 16(2), 1-14.

Ahmed G.A. 2016. Efficiency of some antioxidants and bioagents in controlling Rhizoctonia damping-off of snap bean. Middle East J. of Applied Sci., 6, 748-758.

Ali A.A., Ghoneem K.M., El-Metwally M.A. and Abdel-Hai K.M. 2009. Induce systemic resistance in lupine against root rot diseases. Pakistan J. of Biological Sci., 12, 213- 221.

Almassi F., Ghisalberti E.L., Narbey M.J. and Sivasithamparam K. 1991. New antibiotics from strains of Trichoderma harzianum. J. Nat. Prod., 54, 396-402.

Almeida F.B., dos R., Cerqueira, F.M., Silva, R. do N., Ulhoa C.J. and Lima A.L. 2007. Mycoparasitism studies of Trichoderma harzianum strains against Rhizoctonia solani: evaluation of coiling and hydrolytic enzyme production. Biotechnology Letters, 29, 1189-1193.

Bán R., Baglyas G., Virányi F., Barna B., Posta K., Kiss J. and Körösi K. 2017. The chemical inducer, BTH (benzothiadiazole) and root colonization by mycorrhizal fungi (Glomus spp.) trigger resistance against white rot (Sclerotinia Sclerotiorum) in sunflower. Acta. Biol. Hung., 68, 50-59.

Barilli E., Sillero J.C. and Rubiales D. 2010. Induction of systemic acquired resistance in pea against rust (Uromyces pisi) by exogenous application of biotic and abiotic inducers. J. Phytopathol., 158, 30-34.

Beatty P.H. and Jensen S.E. 2002. Paenibacillus polymyxa produces fusaricidin-type antifungal antibiotics active against Leptosphaeria maculans, the causative agent of blackleg disease of canola. Can. J. Microbiol., 48, 159-169.

Benitez T., Rincon A.M., Limon M.C. and Co-don A.C. 2004. Biocontrol mechanisms of Trichoderma strains. Int. Microbiolo., 7, 249260.

Boeswinkel H.J. 1976. Storage of fungal cultures in water. Trans. Br. Mycol. Soc., 66, 183-185. 
Booth C. 1971. The Genus Fusarium. Commonwealth Mycological Institute, Kew, Surrey, United Kingdom. 237p.

Bovie C., Ongena M., Thonart P. and Dommes J. 2004. Cloning and expression analysis of cDNAs corresponding to genes ac-tivated in cucumber showing systemic acquired resistance after BTH treatment. BMC Plant Biology, 26, 415.

Boyle C. and Walters D. 2005. Induction of systemic protection against rust infection in broad bean by saccharin: effects on plant growth and development. New Phytol., 167, 607-612.

Boyle C. and Walters D.R. 2006. Saccharininduced protection against powdery mildew in barley: effects on growth and phenylpropanoid metabolism. Plant Pathol., 55, 82-91.

Burketova L., Trda L., Ott P.G. and Valentova 0. 2015. Bio-based resistance inducers for sustainable plant protection against pathogens. Biotechnology Advances 33, 994-1004.

Chakraborty M.R. and Chatterjee N.C. 2007. Interaction of Trichoderma harzianum with Fusarium solani during its pathogenesis and the associated resistance of the host. Asian J. Exp. Sci., 21, 351-355.

Chet I. and Inbar J. 1994. Biological control of fungal pathogens. Appl. Biochem Biotechnol., 48, 37-43.

Choong-Min R., Jinwoo K., Okhee C., Seuk H. K. and Chang S.P. 2006. Improvement of biological control capacity of Paenibacillus polymyxa E681 by seed pelleting on sesame. Biological Control, 39, 282-289.

Da Mota F.F., Gomes E.A. and Seldin L. 2008. Auxin production and detection of the gene coding for the auxin efflux carrier (AEC) protein in Paenibacillus polymyxa. J. Microbiol., 56, 257264.

Edreva A. 2004. A novel strategy for plant protection: Induced resistance. Journal of Cell and Molecular Biology, 3, 61-69.

Elhajji M., Rebuffat S., Lecommandeur D. and Bodo B. 1987. Isolation and sequence determination of Trichorzianines: An antifungal peptides from Trichoderma harzianum. International J. of Peptide and Protein Research, 29, 207215.

Elsaid A.M., Shehata S.T., Abd-El-Moity T.H., and Aly M.M. 2005. Evaluation of single or combined isolates of Trichoderma harzianum in different formulations for controlling root rot diseases of strawberry. Annals of Agric. Sci., Ain Shams Univ., Egypt 50, 601-611.

El-Sayed S.A. and Abdel-Monaim M.F. 2017. Integrated control management of root rot disease in lupine plants by using some bio-agents, chemical inducers and fungicides. J. of Plant Sci. and Agric. Research, 1, 1-8.

FAOSTAT. 2019. Data base result 2017, Food and Agriculture Organization of United Nations, http://Fao.org.

Farkas G.L. and Kiraly Z. 1962. Role of phenolic compounds in the physiology of plant diseases and disease resistance. Phytopath. Z., 44, 105150.

Friedrich L., Lawton K., Ruess W., Masner P., Specker N., Gut Rella M., Meier B., Dinch-er S., Staub T., Uknes S., Metraux J.P., Kessmann H. and Ryals J. 1996. A benzothiadiazole derivative induces systemic acquired resistance in tobacco. The Plant J., 10, 61-70.

Gaffney T., Friedrich L., Vernooij B., Negrotto D., Nye G., Uknes S., Ward E., Kessmann H. and Ryals J. 1993. Requirement of salicylic acid for the induction of systemic acquired resistance. Sci., 261, 754-756.

Gaskill J.O. 1968. Breeding for Rhizoctonia resistance in sugar-beet. J. of the American Society of Sugar Beet Technologists 15, 105119.

Ghisalberti E.L. and Rowland C.Y. 1993. Antifungal metabolites from Trichoderma harzianum. J. Nat. Prod., 56, 1799-1804.

Goodman R.N., Kiraly Z. and Zaitlin M. 1967. The Biochemistry and Physiology of Infectious plant Diseases. Van Nostrand Co. Inc., Princeton, New Jersey, 354 p.

Görlach J., Volrath S., Knauf-Beiter G., Hengy G., Beckhove U., Koge K.H.I., Oostendorp M., Staub T., Ward E., Kessmann H. and Ryals J. 1996. Benzothiadiazole, a novel class of inducers of systemic acquired resistance, activates gene expression and disease resistance in wheat. Plant Cell, 8, 629-643.

Grisebach H. 1981. Lignin. In: The Biochemistry of Plants, Vol. 7, Conn E.E., (Ed.). Academic Press, New York, pp. 451-478.

Gross G.G. 1979. Recent advances in chemistry and biochemistry of lignin. Recent Advances in Phytochemistry, 12, 177-220.

Harman G.E., Howell C.R., Viterbo A., Chet I. and Lorito M. 2004. Trichoderma species opportunistic, a virulent plant symbionts. Nature Rev., 2, 43-56.

Hartman G.L., Pawlowski, M.L., Chang H.X. And Hill C.B. 2016. Successful technologies and approaches used to develop and manage resistance against crop diseases and pests. In: Madramootoo, C. (Ed.), Emerging technologies for promoting food security: Overcoming the world food crisis. Wood head Publishing, pp. 43-66. 
He Z., Kisla D., Zhang L., Yuan C.H., GreenChurch K.B. and Yousef A.E. 2007. Isolation and identification of a Paenibacillus polymyxa strain that coproduces a novel lantibiotic and polymyxin. Appl. Environ. Microbiol., 73, 168178.

Idrees M., Naeem N., Aftab T., Khan M.M.A. and Moinuddin 2011. Salicylic acid mitigates salinity stress by improving antioxidant defence system and enhances vincristine and vinblas-tine alkaloids production in periwinkle [Catharanthus roseus (L.) G. Don]. Acta Physiol. Plant, 33, 987-999.

Iriti M., Rossoni M., Borgo M. and Faoro F. 2004. Benzothiadiazole enhances resveratrol and anthocyanin biosynthesis in grapevine, meanwhile improving resistance to Botrytis cinerea. J. Agric. Food Chem., 52, 4406-4413.

Kannojia P., Choudhary K.K., Srivastava A.K. and Singh A.K. 2019. Pgpr bioelicitors: induced systemic resistance (isr) and proteomic perspective on biocontrol. In: Singh, A.K., Kumar A. and Singh P.K. (Eds.), Pgpr amelioration in sustainable agriculture: food security and environmental management. Woodhead Publishing, pp. 67-84.

Katan J. 2017. Diseases caused by soilborne pathogens: Biology, Management and Challenges. J. Plant Pathol., 99, 305-315.

Kumar D. 2014. Salicylic acid signalling in disease resistance. Plant Sci., 228,127-134.

Lamichhane J.R., Dürr C., Schwanck A.A., Robin M.H., Sarthou J.P., Cellier V., Messéan A. and Aubertot J.N. 2017. Integrated management of damping-off diseases: A review. Agron. Sustain. Dev 37(2), 10. https://doi.org/10.1007/s13593-017-0417-y

Leslie J.F. and Summerell B. A. 2006. The Fusarium laboratory manual. Black well Publishing, lowa, USA, 388p.

Mandal, S., Mallick, N. and Mitra, A. 2009. Salicylic acid induced resistance to Fusarium oxysporum f. sp. lycopersici in tomato. Plant Physiology and Biochemistry, 47, 642-649.

Marwa A.M. Atwa, Shehata S.T. and Rahhal M.M.H. 2014. Induction of resistance against soybean damping-off caused by Rhizoctonia solani. Egypt. J. Phytopathol. 42, 137-158.

Meyer A.M. 1987. Polyphenol oxidases in plants recent progress. Phytochemistry, 26, 11-20.

Milford G.F. and Shield I.F. 1996. The potential of lupins for UK Agriculture. J. of the Royal Agric. Society of England, 157, 84-91.

Mona M.M. Ragab, Saber M.M., El-Morsy S.A. and Abeer A.R. Abd El-Aziz 2009. Induction of systemic resistance against root rot of basil us- ing some chemical inducers. Egypt. J. Phytopathol., 37, 59-70.

Muslim A., Horinouchi H. and Hyakumachi M. 2003. Control of Fusarium crown and root rot of tomato with hypovirulent binucleate Rhizoctonia in soil and rock wool systems. Plant Dis. 87, 739-747.

Nafie E. and Mazen M.M. 2008. Chemical induced resistance against brown stem rot in soybean: The effect of benzothiadiazole. J. of Applied Sci. Research, 4, 2046-2064.

Nawrocka J. and Małolepsza U. 2013. Diversity in plant systemic resistance induced by Trichoderma. Biological Control, 67, 149156.

Nicholson R.L. and Hammerschmidt R. 1992. Phenolic compounds and their role In disease resistance. Annual Review of Phytopathology, 30, 369-389.

Oostendorp M., Kunz W., Dietrich B. and Staub T. 2001. Induced disease resistance in plants by chemicals. European J. of Plant Pathology, 107, 19-28.

Papavizas G.C. and Davey C.B. 1962. Isolation and pathogenicity of Rhizoctonia saprophytically existing in soil. Phytopathology, 52, 834-840.

Pichard B., Larue J.P. and Thouvenot D. 1995. Gavaserin and saltavalin, new peptide antibiotics produced by Bacillus polymyxa. FEMS Microbiology Letters, 133, 215-218.

Pieterse C.M.J., Zamioudis C., Berendsen R.L., Weller D.M., Van Wees S.C.M. and Bakker P.A.H.M. 2014. Induced systemic resistance by beneficial microbes. Annu. Rev. Phytopathol, 52, 347-375.

Pii Y., Mimmo T., Tomasi N., Terzano R., Cesco S. and Crecchio C. 2015. Microbial interactions in the rhizosphere: beneficial influences of plant growth promoting rhizobacteria on nutrient acquisition process. A review. Biol. Fertil. Soils, 51, 403-415.

Raza W., Yuan J., Ling N., Huang Q. and Shen Q. 2015. Production of volatile organic compounds by an antagonistic strain Paenibacillus polymyxa WR2 in the presence of root exudates and organic fertilizer and their antifungal activity against Fusarium oxysporum f.sp. niveum. Biological Control, 80, 89-95.

Redda E.T., Ma J., Mei J., Li M., Wu B. and Jiang X. 2018. Antagonistic potential of different isolates of Trichoderma against Fusarium oxysporum, Rhizoctonia solani, and Botrytis cinerea. Eur. Exp. Biol., 8(2), 12.

DOI: $10.21767 / 2248-9215.100053$

Rifai M.A. 1969. A revision of the genus Trichoderma. Mycological Paper 116, 1-56. 
Rini C.R. and Sulochana K.K. 2007. Substrate evaluation for multiplication of Trichoderma spp. J. of Tropical Agric., 45, 58-60.

Sadasivam S. and Manickam A. 1996. Biochemical Methods. $2^{\text {nd }}$ Ed. New Age Int. Pvt. Ltd. Pub. and T.N. Agric. Univ. Coimbatore, Tamil Nadu, India, pp. 108-110.

Samuels G.J. 1996. Trichoderma: a review of biology and systematics of the genus. Mycol. Res. 100, 923-935.

Sarhan E.A.D. and Shehata H.S. 2014. Potential plant growth-promoting activity of Pseudomonas spp. and Bacillus spp. as biocontrol agents against damping-off in Alfalfa. Plant Pathology J., 13, 8-17.

Sarma B.K., Ameer Basha S., Singh D.P. and Singh U.P. 2007. Use of non-conventional chemicals as an alternative approach to protect chickpea (Cicer arietinum) from Sclerotinia stem rot. Crop Prot., 26, 1042-1048.

Sauerborn J., Buschmann H., Ghiasi K.G. and Kogel K.H. 2002. Benzothiadiazole activates resistance in sunflower (Helianthus annuus) to the root-parasitic weed Orobanche cumana. Phytopathology, 92, 59-64.

Shehata S.T., Mosbah M.M. and Hegazi M.F. 2006. Selection of biocontrol agents for control of onion white rot disease. J. Agric. Sci. Mansoura Univ., Mansoura, Egypt, 31, 26212637.

Siegrist J., Mühlenbeck S. and Buchenauer H. 1998. Cultured parsley cells, a model system for the rapid testing of abiotic and natural substances as inducers of systemic acquired resistance. Physiological and Molecular Plant Pathology, 53, 223-238.

Sillero J.C., Rojas-Molina M.M., Avila C.M. and Rubiales D. 2012. Induction of systemic acquired resistance against rust, ascochyta blight and broomrape in faba bean by exogenous application of salicylic acid and benzothiadiazole. Crop Protection, 34, 65-69.

Silva F. and Azevedo C.A.V. 2009. Principal components analysis in the software AssistatStatistical Attendance. In: World Congress on Computers In Agriculture, 7. American Society of Agricultural and Biological Engineers. Reno, NV, USA.

Sneh B., Burpee L. and Ogoshi A. 1991. Identification of Rhizoctonia species. American Phytopathological Society Press, St. Paul, Minnesota. $133 \mathrm{p}$.
Snell F.D. and Snell C.T. 1953. Calorimetric methods of analysis, including some turbidimetric and nephelometric methods. 3rd Ed., Volume III (Organic I), D. Van Nostrand CO. Inc., Princeton, NJ, USA. 606 p.

Srivastava P., George S., Marois J.J., Wright D.L. and Walker D.R. 2011. Saccharin induced systemic acquired resistance against rust (Phakopsora pachyrhizi) infection in soybean: Effects on growth and development. Crop Protection, 30, 726-732.

Sutha R., Ramiah M. and Rajappan K. 1998. Changes in protein and amino acid composition of tomato due to a tospovirus infection. Indian Phytopath., 51, 136-139.

Tewari L. and Bhanu C. 2004. Evaluation of agroindustrial wastes for conidia based inoculum production of biocontrol agent: Trichoderma harzianum. J. of Scientific and Industrial Research 63, 807-812.

Thakur M. and Sohal B.S. 2013. Role of elicitors in inducing resistance in plants against pathogen infection: a review. ISRN Biochemistry: Vol. 2013, Article ID 762412, 10 p.

Timmusk S., Nicander B., Granhall U. and Tillberg E. 1999. Cytokinin production by Paenibacillus polymyxa. Soil Biol. Biochem., 31, 1847-1852.

Vinale F., Marra R., Scala F., Ghisalberti E.L., Lorito M. and Sivasithamparam K. 2006. Major secondary metabolites produced by two commercial Trichoderma strains active against different phytopathogens. Lett. App. Microbiol., 43, 143-148.

Vinale F., Flematti G., Sivasithamparam K., Lorito M., Marra R., Skelton B.W. and Ghisalberti E.L. 2009. Harzianic acid, an antifungal and plant growth promoting metabolite from Trichoderma harzianum. J. Nat. Prod., 72, 2032-2035

Walters D.R., Ratsep J. and Havis N.D. 2013. Controlling crop diseases using induced resistance: challenges for the future. J. Exp. Bot., 64, 1263-1280.

Wang F., Gao R.J., Li J.O., Wu X.H. and Geny P.T. 2000. Effect of difenoconazole on the growth and activities of disease resistance related enzymes in wheat seedlings from treated seeds. Acta Phytopathologica Sinica, 30, 213-216.

Zian A.H. 2011. Studies on Fusarium wilt disease of white lupine plants in Egypt. Ph.D. Thesis, Fac. Agric., Suez Canal Univ., Egypt, pp. 138145. 


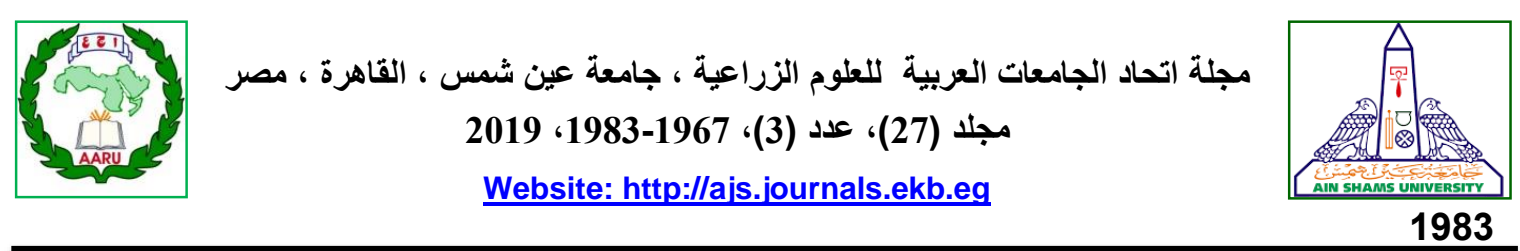

تأثير المستحثات المختلفة علي مكافحة أمراض موت البادرات والذبول في الترمس

[158]

\author{
مروي عبدالله محمود عطوه" - ايهاب علي ضياء سرحان - أحمد حنفي زيان

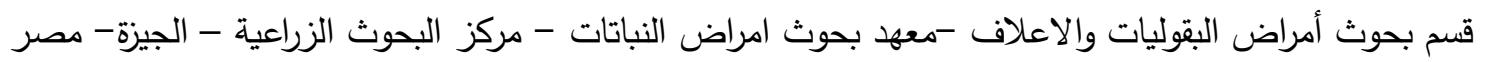 \\ *Corresponding author: marwashehatas@yahoo.com
}

Received 9 July, 2019

Accepted 4 August, 2019

ادت الي زيادة نسبة النباتات الباقية على قيد الحياة

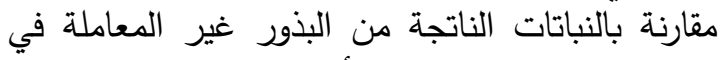
كلا التجربتين. وقد تحققت أعلي نسبة للنبات النباتات الباتية الباتية

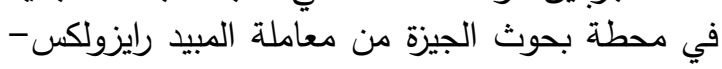

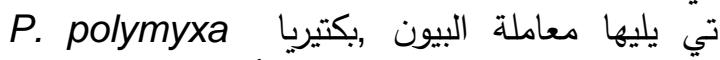
وحامض السلسليك. بينما تحققت البئي أعلي نسبة للنباتات

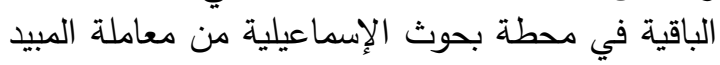

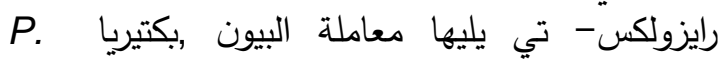
polymyxa

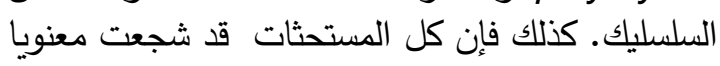

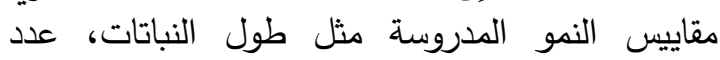
القرون/نبات ووزن البذور /نبات ووزن 100 بذرة مقارنة

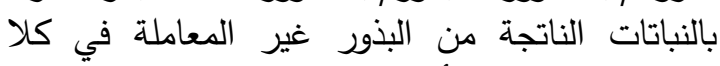

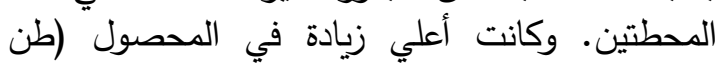

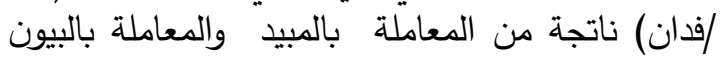

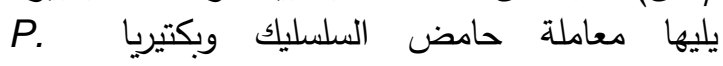

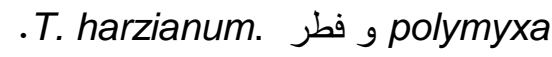
كذلك تم تقدير نشاط إنزيمي البيروكسيديز والبولي

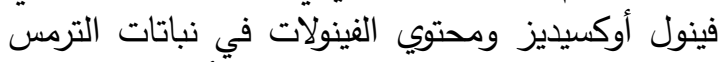

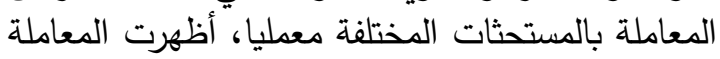

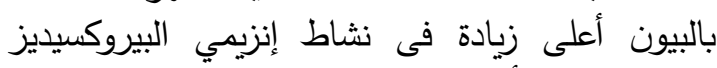

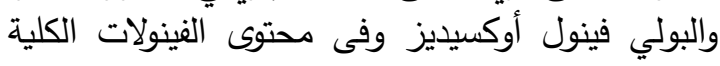
P. يليها ألمعاملة حامض ألسلسيليك وفليك ومعاملة بكتيريا م في وجود الفطر R. solymyxa . F. oxysporum. f. sp. lupine

الكلمات الدالة: الترمس، موت البادرات، الذبول، المقاومة المستحثة الماتة

يهدف هذا البحث إلي دراسة تأثير معاملة بذور الترمس من الصنف جيزة 2 بتركيزات من مواد البير البيون (5 مللي مولر)، حامض السلسليك (5 ملفيز من ملي مولر)

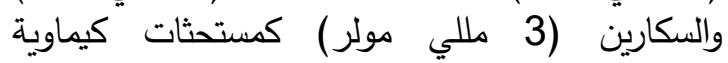
Paenibacillus polymyxa كولالإضافة إلي بكنيات وفطر Trichoderma harzianum كمستحثات حيوية علي الاصابة بفطري

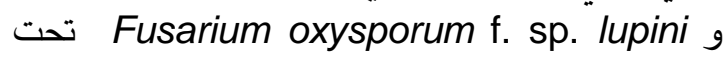

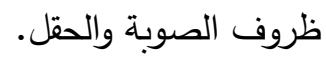

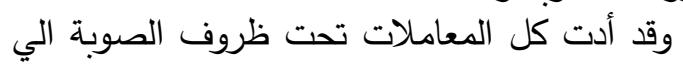

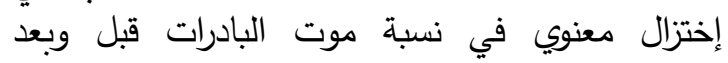

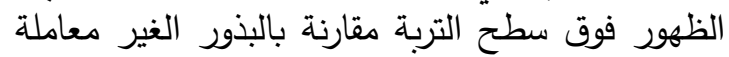

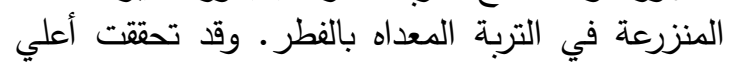

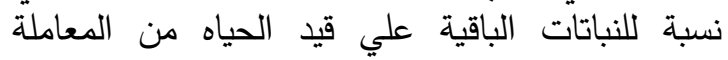

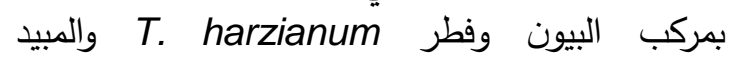
رايزولكس- تي وكانت 92\% يليها المعاملة بحامض

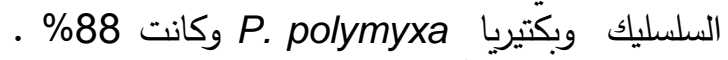
ومن ناحية اخري أدت جميع المعاملات الي الئيل اختزال

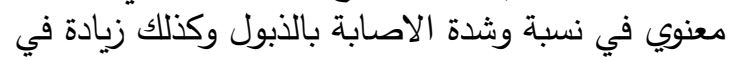

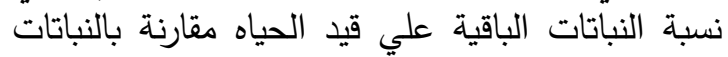

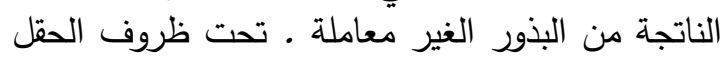
في محطة بحوث الجيزة- محافظة الجيزة و محطة الجئة

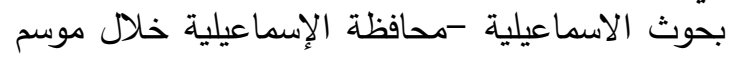

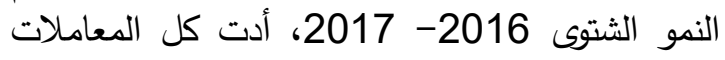

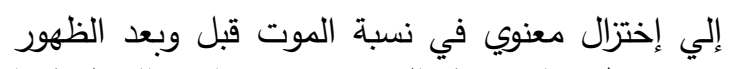
فوق سطح التربة وكذلك نسبة الإصابة بالذبول فئل كما

$$
\text { تدكيم: ا.د مجدى جاد الرب السمان }
$$


أمانى سيد - المراكبي - عفا طلبة - صباح أبو القمصان

Arab Univ. J. Agric. Sci., 27(2), 2019 